\title{
New Zealand Sujon blackcurrant lowers lactate accumulation during cycling in triathletes
}

\author{
Mark ET Willems*', Stephen D Myers, Mandy L Gault, Matthew D Cook \\ From The Eleventh International Society of Sports Nutrition (ISSN) Conference and Expo \\ Clearwater Beach, FL, USA. 20-21 June 2014
}

\section{Background}

Blackcurrant intake has been reported to increase peripheral blood flow in humans [1], potentially by anthocyanin-induced vasorelaxation and vasodilation [2]. Increased peripheral blood flow may affect the exercise intensity at lactate indicators (e.g. onset of blood lactate accumulation (OBLA) at $4 \mathrm{mmol} \mathrm{L}^{-1}$ ) and maximum oxygen uptake. We examined the effect of 1-week Sujon blackcurrant powder supplementation on the blood lactate curve and aerobic capacity of trained triathletes.

\section{Methods}

Healthy male $(\mathrm{n}=8)$ and female $(\mathrm{n}=5)$ triathletes with $>3$ yrs experience (age: $38 \pm 8$ yrs, height: $174 \pm 5 \mathrm{~cm}$, body mass: $71 \pm 9 \mathrm{~kg}$, BMI: $23 \pm 2$, BF\%: $19 \pm 5 \%$, mean $\pm \mathrm{SD}$ ) performed cycling tests for lactate responses (4 min stages with 2 min recovery, start power $50 \mathrm{~W}$ with $30 \mathrm{~W}$ increments) and maximum oxygen uptake (start power $50 \mathrm{~W}$ for 4 min with $30 \mathrm{~W} \mathrm{~min}{ }^{-1}$ increments) at selfselected pedal cadence (SRM ergometer, SRM International, Germany). Familiarized participants were tested following 7 days of Sujon blackcurrant powder (S, 6g/ day) or placebo (P) intake. Experimental design was double-blind and randomized with a wash-out period of 4 weeks. Oxygen consumption (Douglas bag technique) and heart rate were recorded during the cycling tests. Intensity, oxygen uptake and heart rate at $4 \mathrm{mmol} \mathrm{L}^{-1}$ OBLA were calculated using lactate analysis software (Newell et al., 2007). Lactate responses were calculated at relative intensities with individual lactate curves. Paired t-tests were used for analysis with significance accepted at $\mathrm{p}<0.05$. Consent to publish the results was obtained from all participants.

\footnotetext{
* Correspondence: M.Willems@chi.ac.uk

Department of Sport and Exercise Sciences, University of Chichester, Chichester, United Kingdom
}

\section{Results}

The intensity at $4 \mathrm{mmol} \mathrm{L} \mathrm{L}^{-1}$ OBLA was $6 \%$ higher with Sujon (P: $223 \pm 57$, S: $236 \pm 60 \mathrm{~W}$, range -5 to $22 \%, 11$ participants showed an increase and 1 no change). In both conditions at $4 \mathrm{mmol} \mathrm{L}{ }^{-1}$ OBLA, there were no differences in heart rate (P: $159 \pm 7, \mathrm{~S}: 164 \pm 10 \mathrm{~b} \mathrm{~min}^{-1}$, $\mathrm{p}=.13$ ) or oxygen uptake (P: $2.91 \pm 0.73$, S: $2.96 \pm 0.71 \mathrm{~L}$ $\min ^{-1}, \mathrm{p}=.31$ ). Blood lactate was lower at $40 \%(\mathrm{P}: 1.24$ \pm 0.52 , S: $0.91 \pm 0.46 \mathrm{mmol} \mathrm{L}^{-1}$ ), $50 \%$ (P: $1.58 \pm 0.78$, S: $1.23 \pm 0.64 \mathrm{mmol} \mathrm{L}^{-1}$ ), $60 \%$ (P: $2.29 \pm 0.96$, S: $1.91 \pm 0.87$ $\mathrm{mmol} \mathrm{L}^{-1}$ ) and $70 \%$ (P: $3.52 \pm 1.10$, S: $3.08 \pm 1.21 \mathrm{mmol} \mathrm{L}^{-}$ $\left.{ }^{1}\right)$ of maximum power, decreases of $27 \%, 22 \%, 17 \%$ and $13 \%$, respectively. There was no effect on maximum values of oxygen uptake (P: 49.1 \pm 6.2 , S: $49.7 \pm 6.1 \mathrm{~mL} \mathrm{~kg}$ ${ }^{1} \mathrm{~min}^{-1}$ ), power (P: $305 \pm 68, \mathrm{~S}: 307 \pm 62 \mathrm{~W}$ ) or heart rate (P: $172 \pm 10$, S: $172 \pm 11 \mathrm{~b} \mathrm{~min}^{-1}$ ). However, maximum oxygen uptake with Sujon was obtained with $14 \%$ lower lactate values (measured 3-min after exhaustion; P: 7.85 \pm 1.69 , S: $6.79 \pm 1.51 \mathrm{mmol} \mathrm{L}^{-1}$, range -27 to $48 \%, 10$ participants showed a decrease and 1 no change).

\section{Conclusions}

Intake of New Zealand Sujon blackcurrant powder is associated with 1) a substantial downward and rightward shift of the lactate curve during cycling over a wide range of intensities, and 2) lower lactate accumulation at aerobic capacity suggesting increased lactate clearance or altered substrate oxidation. These findings may have implications for training practice and aerobic performance of endurance athletes.

\section{Acknowledgement}

Funding for this study and conference attendance was provided by the University of Chichester, Health Currancy Ltd (UK) and Gibb Holdings (Nelson) Ltd (NZ). 


\section{References}

1. Matsumoto H, Kamm KE, Stull JT, Azuma H: Delphinidin-3-rutinoside relaxes the bovine ciliary smooth muscle through activation of ETB receptor and NO/cGMP pathway. Exp Eye Res 2005, 80(3):313-22.

2. Ziberna L, Kim JH, Auger C, Passamonti S, Schini-Kerth V: Role of endothelial cell membrane transport in red wine polyphenols-induced coronary vasorelaxation: involvement of bilitranslocase. Food Funct 2013, 4(10):1452-6.

doi:10.1186/1550-2783-11-S1-P2

Cite this article as: Willems et al: New Zealand Sujon blackcurrant

lowers lactate accumulation during cycling in triathletes. Journal of the International Society of Sports Nutrition 2014 11(Suppl 1):P2.

Submit your next manuscript to BioMed Central and take full advantage of:

- Convenient online submission

- Thorough peer review

- No space constraints or color figure charges

- Immediate publication on acceptance

- Inclusion in PubMed, CAS, Scopus and Google Scholar

- Research which is freely available for redistribution

Submit your manuscript at www.biomedcentral.com/submit
Ciomed Central 